\title{
Natureza e sociedade: a controvérsia sobre os alicerces da conduta humana
}

\author{
Ademar HEEMANN
}

\begin{abstract}
RESUMO
Esta reflexão procura contribuir para o entendimento das dimensões epistemológica e ética que circundam a questão ambiental e, de um modo mais específico, as reivindicações dos movimentos de amor à natureza. Para tanto, argumenta-se sobre a necessidade de uma compreensão da demarche que procura extrair da ordem natural os indicativos para a conduta humana. Essa é mais uma invenção grega, daí porque são revisitadas as rupturas com o mundo mítico e religioso. Com essa intenção é construída uma problemática em face das visões fundacionista e relativista da legitimação ética.
\end{abstract}

Palavras-chave: Natureza, Ética, Meio Ambiente

\begin{abstract}
This reflection aims at contributing to the understanding of both the epistemological and the ethical dimension that encircle the environmental issue, and , more specifically, the demands from the movements that love nature. For this reason, it debates about the need to an understanding of the demarche that tries to extract from the natural order the clues for the human conduct. This is another Greek invention and that is why the ruptures with the mythical world are reviewed.

It is bearing this intention that a question is posed according to the both the Foundationist and Relativist vision of ethical legitimization.
\end{abstract}

Key words: Nature, Ethic, Environment

* E-mail: heemann@bbs2.sul.com.br 


\section{$O$ alicerce Perene}

\section{Do mito ao naturalismo grego: uma troca de ído-} los?

Diz-se que antes do milagre grego $^{1}$ o sentido da existência só poderia se escorar em mitos e divindades. Os valores caíam do céu, mediados pela voz do soberano, que de modo indiscutível ditava o significado e o destino de todos. Com autoridade irrestrita, essa figura divina concentrava todos os poderes e legitimava o certo e o errado, o bem e o mal. Não havia as delimitações da malha normativa, mais tarde criadas, que separaram, por exemplo, a ética da religião.

Essa garantia de um alicerce sobrenatural para a definição do bem, no entanto, foi irreversivelmente solapada por um pensamento desmitificador iniciado na Grécia antiga. Novas relações, propiciadas pelo encontro das pessoas no comércio e nas guerras, revelaram a existência de uma infinidade de ordenamentos sobrenaturais. Cada um deles era tido como único e eterno pelos seus seguidores. Corroída estava a confiança nesse modo de ver e pensar o mundo. Daí que alguns sábios inventaram uma outra cosmovisão. Através de uma racionalidade introspectiva, entronizaram a natureza no lugar da divindade.

Esse tipo de racionalidade deu início à grande aventura intelectual e existencial da dessacralização do mundo. Uma ruptura abismal com a visão até então disponível, apesar de conservar o substrato externo ao homem para conferir significado e fundamento ao seu agir. ${ }^{2} \mathrm{O}$ milagre grego! Significou a dispensa do não-natural na explicação do universo. Essa passagem da visão mítica ${ }^{3}$ para o naturalismo metafísico não seria apenas uma substituição de ídolos? Uma nova ilusão?

\begin{tabular}{|c|c|}
\hline Antigüidade & 600 a C. $\rightarrow$ \\
\hline $\begin{array}{l}\text { O soberano: uma figura divina do } \\
\text { soberano } \\
\text { (Autoridade irrestrita) }\end{array}$ & $\begin{array}{l}\text { Primórdios da filosofia grega } \\
\text { (Racionalidade) }\end{array}$ \\
\hline O MITO E A RELIGIÃO & $\begin{array}{l}\text { O NATURALISMO } \\
\text { METAFÍSICO }\end{array}$ \\
\hline $\begin{array}{l}\text { ESFERAS NORMATIVAS } \\
\text { INDIFERENCIADAS }\end{array}$ & $\begin{array}{l}\text { DIFERENCIAÇÃO DA MALHA } \\
\text { NORMATIVA (ética, justiça, religião) }\end{array}$ \\
\hline
\end{tabular}

Esquema - Do mítico-religioso à razão metafísica

\section{Agir conforme a natureza}

Esse imperativo ético foi idealizado por uma demarche que aspirou, em primeiro lugar, a uma ordem explicativa para o mundo físico. Para tanto, seus arquitetos necessitaram de um princípio material de sustentação, um ponto de partida, sem deuses e mistérios. Conceberam, então, a idéia do elemento primordial, o substrato que garantiria a compreensão de toda a realidade. Feito isso, estabeleceram, a seu modo, que a ordem do mundo físico também é válida para fundar o agir humano. ${ }^{4}$

Mas o que é a natureza? ${ }^{5}$ Essa indagação remete ao termo essência: o cerne do pensamento metafísico. Aqui, o conceito ${ }^{6}$ foi intencionalmente simplificado. Trata-se, apenas, de facilitar a compreensão dessa racionalidade, que pretende transpor a ordem física para a ordem ética, e de como essa idéia chegou e se perpetua no mundo atual.

1 O nascimento da razão metafísica, em torno de 600 a. C.

2 Adiante serão feitas novas incursões ao tema em virtude de seu interesse para o debate contemporâneo, que reúne, entre outros, setores ecologistas que reivindicam a existência de valores inerentes à natureza.

3 O mito, no entanto, nunca deixou de ser uma forma de conhecimento e de linguagem que, ainda hoje, continua a alimentar o pensamento.

4 O recurso para essa pretensa validação será visto, adiante, no item "A premissa oculta". Na Ética a Nicômaco, Aristóteles discorre sobre a virtude, que implica viver de acordo com a natureza. Aristóteles. Ética a Nicômaco. In: Os Pensadores. São Paulo: Abril Cultural, 1973. v.9, p. 256.

5 A plurissignificação do termo natureza gera muitos equívocos e uma infindável polêmica. Ver também Lenoble, Robert. História da idéia de natureza. Rio de Janeiro: Edições 70, 1990; Whitehead, Alfred North. O conceito de natureza. São Paulo: Martins Fontes, 1993 e Casini, Paolo. As filosofias da natureza. Lisboa: Editorial Presença, 1979.

$6 \mathrm{Na}$ gênese do conceito de natureza se entrelaçam as idéias de arkhe, aitia, eidos e morphe. 
Segundo essa concepção metafísica, todos os seres (entes) possuem uma essência. Significa que há um modo de ser. Agir adequadamente (ética) implica realizar o modo de ser, a essência. É a noção de projeto, de algo preestabelecido. Sob esse olhar, já existe o bem (valor), inerente à natureza. Não se trata, portanto, de inventálo, mas de realizá-lo. Assim, de alguma forma, o bem deve ser decifrado pelo hermeneuta ${ }^{7}$ da natureza, que interpreta seus mistérios ocultos, sua finalidade.

\section{A causa não causada}

O olhar científico minou a idéia finalística. Ele é desmitificador. Já não haveria mais sentido oculto nem finalidade ética predeterminada na natureza. Ela seria neutra. A hipótese precursora desse jeito de ver o mundo recua a Protágoras (485-410 a.C.), mas sua consolidação se deve aos pensadores da existência. Alguns desdobramentos desse pensamento levaram a um modo cético e pessimista de ver o mundo, denominado pelos seus detratores como ideologia do desencanto. ${ }^{8}$

Sob o teto científico, a causa será entendida de maneira radicalmente diversa da perspectiva metafísica. Veja-se, por exemplo, o enunciado de que o calor dilata os corpos. A conjectura é de que a dilatação de um corpo ocorre em função da temperatura: $\mathrm{D}=\mathrm{f}(\mathrm{T})$. A causalidade é aqui entendida como a relação constante entre fenômenos, daí o conceito de lei científica para expressála. ${ }^{9}$

Essa é a base do método científico: o reducionismo. É o processo/método que procura reduzir o fenômeno à causa. Obtendo-se o nexo causa/efeito, tem-se a explicação. Trata-se de uma racionalidade restrita à relação causal entre as variáveis envolvidas no fenômeno.
Diversamente, sob a racionalidade metafísica interpretava-se a dilatação de um corpo mediante a reflexão sobre a essência (finalidade ou propósito) do calor. É a perspectiva teleológica (telos $=$ fim), que transfere o propósito, um atributo humano, para o mundo natural sob a denominação de causa final. O exemplo que segue $^{10}$ ilustra essa transferência.

- Por que a vidraça se quebrou? Qual a causa?

- A vidraça se quebrou (efeito) porque o menino atirou a pedra (causa).

- Por que o menino atirou a pedra? Qual era o seu propósito?

Estendendo o propósito humano para um fenômeno da natureza, tem-se a explicação teleológico-metafísica. Assim, Aristóteles ${ }^{11}$ daria conta de um fenômeno natural como a chuva através das causas primeiras (arkhes aitíon) conforme segue.

\begin{tabular}{c|c|c|c}
\hline \multicolumn{4}{c}{ Causas } \\
\hline Material & Atuante & Formal & Final \\
\hline $\begin{array}{c}\text { (substancial) } \\
\text { - O vapor }\end{array}$ & $\begin{array}{c}\text { (eficiente) } \\
\text { Esfriamento } \\
\text { do vapor }\end{array}$ & $\begin{array}{c}\text { - É inerente à } \\
\text { forma da água } \\
\text { cair no chão }\end{array}$ & $\begin{array}{c}\text { - Há nas gotas o } \\
\text { propósito de } \\
\text { saciar a sede } \\
\text { dos seres }\end{array}$ \\
\hline
\end{tabular}

Na ilustração, a causa final é a mais importante porque trata da orientação (saciar a sede) e da realização do ser. Assim, para o fenômeno meteorológico é atribuído um propósito. Há um propósito inserido nas gotas da chuva (saciar a sede, molhar as plantas). Daí a irredutibilidade ou incomensurabilidade com o reducionismo científico, que explicará o fenômeno da chuva em termos de pressão atmosférica, umidade do ar, temperatura e força da gravidade.

7 Hermeneuein, gr. = interpretar. Ver em Heemann, Natureza e ética, p. 165-174, uma abordagem hermenêutica de um discurso do cientista.

8 Heemann, Ademar. O desencanto: ideologia do pessimismo? In: ____ Natureza e ética. Curitiba: 1998, p.182-194.

9 Baseado na didática exposição de Severino, Antônio Joaquim. Filosofia. São Paulo: Cortez, 1994, p.120,121. Ver tb. Giovanni, Reale. História da filosofia antiga: v. 5. Léxico, índices, bibliografia. São Paulo: Loyola, 1995. p.43-44.

10 Baseado em exemplo de Gaarder, Jostein. O mundo de Sofia: romance da história da filosofia. São Paulo: Companhia das Letras, 1995 , p. 126,127 .

11 Sobre o conjunto de causas (aitiai), veja-se Aristóteles. Metafísica, I, 3, 983a 24-33. 


\section{Princípio e fim: o fundamento}

Para a visão teleológica (finalista) há uma ordem (ética) preestabelecida na natureza, ela tem um fim em si, havendo, portanto, um projeto a ser realizado. Trata-se, então, de saber qual é essa ordem para se poder segui-la.

Para tanto, o hermeneuta (intérprete) da natureza terá que mergulhar em sua reflexividade intuitiva e valerse de categorias como essência, princípio, causa e fim. Para entender essa construção, convém esquecer, temporariamente, o conceito de causa e efeito (da ciência) bem como a visão de início e de fim, legada pela perspectiva hebraico-cristã, para visualizar a alternativa grega de um universo eterno.

\begin{tabular}{cc}
\multicolumn{3}{c}{ Perspectiva hebraico-cristã } \\
$(\alpha)$ & DEUS \\
PRINCÍPIO & FIM
\end{tabular}

Perspectiva grega

\begin{tabular}{|c|c|c|}
\hline $\begin{array}{c}\text { Ponto de partida } \\
\text { (Arkhe) }\end{array}$ & & Causa final \\
\hline PRINCÍPIO & $\begin{array}{c}\text { NATUREZA } \\
\text { Eterna }\end{array}$ & FINALIDADE \\
\hline
\end{tabular}

Inicialmente, o elemento primordial (physis, gr. e natura, lat.) do universo era a referência para toda a realidade. Aristóteles amplia essa construção com a idéia das causas. Isso permite aproximar os termos princípio (arkhe) e causa (final, télos), ou razão de ser.
Portanto, a finalidade é causa (final), que já está contida no princípio. Em parte, é como se entende um projeto. Nele, o princípio e o fim já estão determinados. Em suma, o que interessa para os limites dessa reflexão é o entendimento do significado teleológico, segundo o qual, inerente à natureza existe a finalidade, o sentido. ${ }^{12}$ Daí em diante não se admite mais nenhuma indagação. Trata-se do último porquê, de uma razão auto-sustentável. É o recurso derradeiro e perene. É o fundamento do agir (ético). ${ }^{13}$

\section{Os alicerces perenes}

O desfile de "alicerces perenes" é ininterrupto. ${ }^{14}$ $\mathrm{Na}$ Antigüidade as preocupações cosmológicas que originaram todos aqueles enunciados: no princípio era a água; no princípio era o fogo; no princípio era o indeterminado; no princípio era o número; no princípio era o céu.

Vale destacar esse último enunciado, de Platão, que reaparece três séculos mais tarde, em parte, no texto cristão (helenizado) sobre a versão hebraica da criação: no princípio era o verbo.

Nessa busca pelas relações secretas entre o homem e a natureza, os pitagóricos (no VI séc. a C.) celebraram a harmonia dos números na descrição do mundo natural. Enunciaram que o número era princípio e essência de todas as coisas. Era uma aspiração estética que lhes permitiu alicerçar a passagem para a dimensão ética mediante o raciocínio de que o quadrado de um número é harmônico e tem partes iguais. Logo, os Estados deverão ser divididos em partes iguais e subsidiados eqüitativamente. Essa lógica lhes possibilitou uma ordem

12 Muitos homens de ciência se envolveram em dificuldades epistemológicas ao tentaram algum tipo de concordismo entre a redução científica e a metafísica e/ou religião. Daí os conceitos como vitalismo, entelequia, entre outros. Um concordismo entre religião e evolucionismo se encontra na obra de Chardin, Teilhard. O fenômeno humano. São Paulo: Herder, 1965. Estaria Maturana, quando se refere ao fundamento biológico da ética, tentando algum tipo de concordismo entre a ciência e o discurso cristão do amor? Esse assunto será retomado mais adiante.

13 Moser, A. Y-a-t-il un fondement scientifique de l'étique? Louvain, 1974. Tese de Doutorado, Université de Louvain.

14 Embora sem aquela dimensão cosmo-teleológica grega, persiste em pensadores como Habermas (ética da comunicação) e Maturana (ética do amor) um tipo de pretensão fundacionista que se contrapõe ao relativismo, ou pluralismo, como preferem alguns a exemplo de Berlin, Isaiah. Vico e Herder. Brasília: Ed. da Universidade de Brasília, 1983. Habermas e Apel dizem que "uma fundação última da ética não é nem possível nem necessária” (Erläuterungen zur Diskursethik, 1991). Ao longo da presente reflexão persiste a indagação se existe algum outro tipo de fundamentação que resista à interdição de D. Hume (Conferir, mais adiante, no item Falácia Naturalista). 
social em sincronia com a ordem natural. ${ }^{15}$

A esse período de preocupações cosmocêntricas, segue-se "o conhece-te a ti mesmo" socrático (469 a C.). O conceito de natureza estará centrado, daí para frente, no homem. Aristóteles (385-322 a C.) dirá que o homem é um animal racional, pois a função própria (ergon) do homem é o uso da razão. ${ }^{16}$ Logo depois, conforme ilustrado abaixo, o estoicismo argumentará que a natureza rege tudo e a razão é o distintivo da natureza humana.

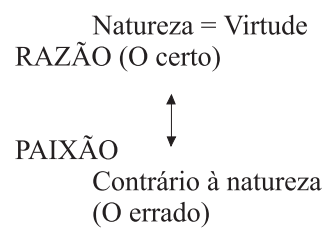

Em consequiência, sendo certo (o bem) o que está de acordo com a natureza, segue-se que viver moralmente implica viver segundo a razão. Ora, se a natureza é definida pela razão e sendo as paixões contrárias à razão, conclui-se que a virtude consiste em dominar as paixões. ${ }^{17}$ Esse racionalismo grego, mais tarde sob as vestimentas da religião, marcou de modo definitivo a nossa civilização. Um retrocesso?

\section{A razão tutelada}

A idéia da razão como princípio hermenêutico da natureza foi transposta para o pensamento religioso, ficando sob a sua tutela. Foi assim que chegou até nós. Como foi possível instaurar esse domínio, uma vez que anteriormente (600 a.C.) já havia ocorrido a ruptura com a esfera mítico-religiosa?

Dentre os vários fatores que ajudam a compreender esse retorno do elemento religioso, há que se consi- derar o fenômeno da helenização. É o pensamento grego que se difunde e deixa suas marcas na dissidência judaica que originou, mais tarde, o cristianismo. Um sinal dessa influência está na utilização da língua grega para os escritos do Novo Testamento. Outro fator a ser considerado é a liberdade para a nova religião, garantida pelo imperador Constantino.

\begin{tabular}{c|c}
\hline a. D. & 313 d. C \\
\hline Era cristã & Medievalismo \\
\hline $\begin{array}{c}\text { Heleniza-se a dissidência } \\
\text { judaíca } \\
\downarrow \\
\text { (cristãos) }\end{array}$ & $\begin{array}{c}\text { Constantino: liberdade cristã } \\
\text { Teocentrismo } \\
\downarrow \\
\text { Síntese grego-cristã sob a tutela } \\
\text { religiosa }\end{array}$ \\
\hline
\end{tabular}

Esquema - Da racionalidade metafísica à tutela religiosa

Esses são alguns antecedentes da síntese entre a tradição judaico-cristã com o pensamento grego, construída no período medieval, sob a primazia religiosa. Diz-se, por isso, que Platão e Aristóteles foram cristianizados.

Assim, pretendeu-se conciliar a razão e o pensamento religioso. Apesar da ruptura instaurada com o renascimento ${ }^{19}$ e seus desdobramentos futuros (Reforma, Iluminismo), os reflexos da síntese medieval ainda determinam, em grande parte, os rumos no debate contemporâneo da legitimação ética.

\section{Nascentes da controvérsia naturalista}

Olhando novamente para trás, para a Antigüidade grega, quando os sábios aparentemente já tinham superado o conflito entre os deuses e a razão, pode-se compreender a transferência de suas preocupações para uma

15 Baseado em Barker, Ernest. Teoria política grega. Platão e seus predecessores. Brasília: Ed. da UNB, 1978, p.58-63, fez-se uma primeira incursão a esse tema em Heemann, Ademar. Natureza e ética. Curitiba: Ed. da UFPR, 1998, em especial nas p.72-80. Sobre os pitagóricos ver tb. Gleiser, Marcelo. A dança do universo: dos mitos da criação ao Big Bang. São Paulo: Companhia das Letras, 1997 , p. 55-58.

16 Aristóteles. Ética a Nicômaco. In: Os Pensadores. São Paulo: Abril Cultural, 1973. v. 9. p. 256.

17 Reale, Giovanni. Storia della filosofia atica. Milano: Vita e Pensiero, 1979, v. 1, p. 264-68.

19 O ano 1400 d.C. marca o renascer (Renascimento), movimento de retorno à cultura clássica grega (sem a tutela da religião) bem como aos textos bíblicos (separando-os da tradição e das categorias do racionalismo grego). O plano político-econômico se caracteriza pelo anticentralismo, pela decadência do feudalismo e pela ascensão mercantilista. 
outra esfera, a do conflito natureza versus sociedade.

Travestido sob vários discursos, desde os gregos, passando pelo período medieval e o modernismo, ele se arrasta até hoje. Um exemplo que despertou grande atenção foram os confrontos entre a etologia ${ }^{20}$ e as humanidades. Ultimamente, o enfoque tem recaído nas reivindicações teleológicas de setores do ecologismo e de movimentos místicos de um modo geral. ${ }^{21}$

\begin{tabular}{c|c|c}
\hline Mágico-religiosa & Metafísica & Científica \\
\hline $\begin{array}{c}\text { Teleológica } \\
\text { Finalismo: causas } \\
\text { mágicas, sobrenaturais } \\
\text { e valores da divindade }\end{array}$ & $\begin{array}{c}\text { Teleológica } \\
\text { Finalismo: causas } \\
\text { "naturais", essencialismo } \\
\text { imutável e valores } \\
\text { inerentes à natureza }\end{array}$ & $\begin{array}{c}\text { Teleonômica } \\
\text { Finalismo aparente: } \\
\text { causas naturais, } \\
\text { dinâmica evolucionária, } \\
\text { sem valores inerentes à } \\
\text { natureza }\end{array}$ \\
\hline
\end{tabular}

Esquema - Um pano de fundo para as concepções naturalistas ${ }^{22}$

O significante (natureza) é o mesmo, mudam os significados. A plurissignificação e a generalidade do termo se alimentaria em três fontes básicas: mítico-religiosa, metafísica e empírica.

$\mathrm{Na}$ aurora do pensamento metafísico, portanto, gera-se a oposição natureza versus sociedade. A natureza é a fonte das leis não escritas (agrafoi nomoi), e a sociedade cria as leis escritas e mutáveis (nomos). Nesse conflito, é relevante o papel dos sofistas (segunda metade do séc. V a.C.), um movimento também visto como subversivo, iconoclasta, questionador. Ele inverte os papéis: recorre à natureza para julgar o próprio Estado e as leis positivas, que são frutos das convenções. Seus variados ensinamentos também confrontam a ordem vigente. Como todos os homens participam da natureza comum da humanidade, os sofistas atacam a distinção entre gregos e bárbaros, nobres e plebeus, livres e escravos. Interessam-se pela situação da mulher e minam a religião, pois acreditam que os deuses são produtos das diversas convenções. Nesse sentido, confrontam-se com Platão (427-347 a.C.), para quem a verdade e a justiça são idéias eternas e implícitas nas convenções, e com Aristóteles (384-322 a.C.), que admite como natural o nascimento de uns para dominar e de outros para a escravidão. ${ }^{23}$

Isso ilustra o uso alternado do conceito de natureza. Ele se reinscreve nas diversas ideologias, tanto para a manutenção como para a subversão da ordem. Essa argumentação pode, por um lado, fragilizar o intento fundacionista que reivindica o alicerce perene e, por outro, pode reforçar a demarche relativista, pois "se é o povo que faz as leis, [não] está claro que o homem é a medida de todas as coisas"? 24

No entanto, se ainda não esmoreceu o intento de uma ética fundada, pelo menos nesse plano fatual ou natural, seria o momento de trazer em cena um outro tipo de intervenção. Ela demonstrará que a lógica formal em si não pode ser utilizada como argumento fundacionista. É o que será analisado na próxima incursão. Trata-se do argumento, segundo o qual, não havendo norma que instaure o imperativo (agir conforme a natureza), também não será possível derivar logicamente da natureza aquilo que deve ser no plano ético.

\section{A falácia naturalista}

\section{O argumento lógico}

Quando as normas eram legitimadas pelas tradições e pelo soberano, o porta-voz divino, poderia existir algum sentimento de segurança. Investindo-se contra as certezas do mito, produziram-se incertezas. Se o fundamento mítico já não servia, sem ele, onde escorar as crenças éticas? Naqueles tempos restou a natureza, uma instância que não é mágica nem revelada, mas construída pela razão idealista. Imaginaram os sábios que o universo seria explicado a partir de um elemento primordial (physis, natura). Esse elemento também seria o princípio

20 Etologia: ramo da biologia que se dedica ao estudo do comportamento.

21 Há uma extensa gama de designações relacionadas a esses movimentos que, em geral, proclamam algum tipo de sincretismo sob termos como holismo, alternativismo ou, ainda, neo-ocultismo, nova religiosidade, etc.

22 Baseado em Heemann, op. cit., p. 87.

23 Veja-se em Heemann, op. cit. p. 75,76, uma abordagem inicial desse tema, que teve como referências Barker p. 58 - 81; Reale, Giovanni, op. cit., p.264-268 e Aristóteles. A política. São Paulo: Atenas, p.10.

24 Schüler, Donaldo. O homem que não sabia jogar. Porto Alegre: 1998, p. 37, no contexto de sua reflexão sobre Protágoras. 
ordenador para o homem; seria o fundamento ultimo da ética. Nesse contexto, o "bem” não natural (ético) seria inerente ao plano natural. Assim, as normas éticas seriam extraídas necessária e logicamente da natureza.

Apesar das interdições a essa pretensão fundacionista, ela foi incrementada com outras racionalizações ao longo dos séculos, chegando sob diferentes roupagens aos dias de hoje. A interdição da lógica formal a essa tentativa dedutora, que procura extrair o "deve ser" (norma ética) de um "é" (plano natural), será aqui ilustrada através de argumentos ${ }^{25}$ montados de um modo simplificado, conforme segue.

Argumento pró-amor:

Premissas: 1. A natureza é (contém) o amor

2. O homem é um ser da natureza

Conclusão válida: $\quad$ O homem é um ser amoroso

Conclusão inválida: O homem "deve" amar

Argumento pró-egoísmo:

Premissas: 3. A natureza é egoísta

4. O homem é um ser da natureza

Conclusão: $\quad$ O homem é um ser egoísta

Conclusão inválida: O homem “deve ser" egoísta

Aqui, a primeira exigência à validade do argumento é a suposição da validade do conteúdo das premissas. Essa suposição permitirá, então, o cumprimento da exigência básica, ou seja: verificar exclusivamente se a conclusão decorre (deriva) das suposições (premissas) enunciadas.

Portanto, em um dos argumentos se afirma o amor e no outro o egoísmo. Ambos descrevem conteúdos (antagônicos) da suposta natureza humana. Não prescrevem (norma ética) o que o homem "deve ser", apenas descrevem como ele "é".

Ora, se as premissas apenas descrevem (operador “é”), a conclusão também terá que descrever, permanecendo com o mesmo operador. Portanto, se na conclusão surgir o “deve ser”, o argumento será inválido, porquanto foi ali introduzido um operador que não está presente nas premissas. Diz-se, nesse caso, que os termos da conclusão extrapolam os termos das premissas. ${ }^{26}$

Então, restaria a pergunta sobre a possibilidade de suprir essa exigência mediante uma premissa subtendida, que pudesse permitir uma conclusão imperativa.

\section{O recurso da premisssa oculta}

Há um contra-argumento do fundacionismo que alega a existência de uma premissa inicial (pressuposta, intuitiva ou evidente por si mesma), que não aparece no argumento, mas que garante o imperativo ("devo amar", por exemplo) na conclusão. Tal pressuposto oculto estabelece que a natureza "deve ser" seguida.

A contestação, por sua vez, indaga: de onde, a premissa oculta? De onde, a norma que valida o "agir conforme a natureza"? De onde, a norma da norma? Essa metanorma, ou ainda, essa causa não causada seria instância derradeira, o fundamento último pretendido.

Esse apelo ao último apoio é uma exigência da condição humana que não pode ser suprida no plano científico e filosófico? Um grande número de sábios entende ser possível racionalizar essa questão fundamental. Referem-se a uma auto-evidência ou conclusão inevitável.

Nesse sentido, os gregos forneceram a premissa oculta. Residiria no fato de que todo o ser tende a se apropriar daquilo que o torna apto a se conservar, evitando o que lhe é contrário. Essa tendência (oikeíosis, gr. $)^{27}$ poderia ser denominada, em um horizonte mais re-

25 Uma exposição didática sobre a estrutura de um argumento lógico se encontra em Nahra, Cinara; Weber, Ivan Ingo. Através da lógica. Petrópolis: Vozes, 1997.

26 Essa é a clássica interdição realizada por David Hume, em 1740, e denominada naturalistic fallacy por Moore, em 1903. Conforme Moore, George Edward. Principia ethica. Cambridge: Cambridge University Press, 1968. p. 10. Castoriadis tem utilizado a expressão "deslize lógico" para designar esse equívoco no âmbito normativo, questionando, inclusive a pretensão fundacionista de Habermas. Cf. Castoriadis, Cornelius. A voga humanista oculta ausência de política: Entrevista concedida a Fernando Barros e Silva. Folha de São Paulo, 7. set./1991. Letras, p. 6-6. Ver tb. Castoriadis. As encruzilhadas do labirinto II: os domínios do homem. Rio de Janeiro: Paz e Terra, 1987.

27 Conforme Reale, Giovanni. Storia della filosofia atica. v. 1. Milano: vita e pensiero, 1979. p. 390-391. 
cente, como instinto de conservação. Esse determinismo teria levado Aristóteles a afirmar que o bom era aquilo para o que todas as coisas tendem. Não chegar a esta conclusão seria um contra-senso, uma tolice. ${ }^{28}$

No debate atual, Maturana, ao referir-se à base natural como fundamento da ética do amor, afirma que não aceitar essa identidade seria um auto-engano, uma ilogicidade que equivale a "no permitir se ver que las manzanas caen hacia abajo." Maturana não estaria vulnerável, como tantos outros, ao argumento demolidor, denominado "guilhotina" de David Hume? ${ }^{29}$

Enunciados da moda, como os que seguem, também não evidenciariam o pano de fundo desse conflito entre valoração humana versus valores inerentes à natureza?

- Paisagem acalmante! - A paisagem é acalmante em-si-mesma ou é o ser humano que se acalma em contato com ela?

- Santuário ecológico! - Há uma relação intrínseca (inerente) entre o caráter da sacralidade e o ambiente natural?

Existe uma demanda que se estende da natureza provida de valor até o observador ou é o observador que atribui valor à natureza? Tais indagações, nos termos dessa argumentação, poderão ser respondidas de modo divergente, em função de duas concepções gerais de natureza, conforme o esquema: ${ }^{30}$

\section{Concepção teleológica}

Fruto da introspecção, essa concepção pretende uma hermenêutica da natureza para interpretar-lhe os significados imanentes ou inerentes. De origem grega, acoplada à patrística e escolástica, convive com alguns setores da filosofia hodierna e com a teologia. Existem tentativas de aproximá-la da teoria da evolução. ${ }^{31} \mathrm{O}$ “bem” seria, então, aquilo que o curso da evolução indica em termos de uma predeterminação última. A pretensão de se amparar na lógica formal se transforma no alvo predileto para aqueles que se valem do argumento de David Hume para desautorizá-la.

\section{Concepção teleonômica}

De cunho materialista, ela se limita aos termos da metodologia científica. Não trata, portanto, de finalismos preestabelecidos ou inerentes à natureza. Só reconhece finalismos funcionais e decorrentes dos processos evolutivos, porquanto as leis naturais não denotam valores. As descrições de seus conteúdos procedem de vários campos da ciência, tendo como pano de fundo a teoria evolucionária.

\section{A falácia informal}

Se o fundacionismo se inviabiliza nesse nível lógico-formal, ele recupera, no entanto, sua força persuasória na esfera emocional. Haveria uma necessidade, uma outra lógica para dar conta desse anseio do universal e perene? Não serão aqui considerados os inúmeros artifícios lingüísticos que desbordam ou ignoram a interdição de David Hume. Basta uma breve alusão sobre essa certeza advinda de uma "lógica" da sedução, aqui denominada de falácia informal.

A falácia informal é aquela idéia aparentemente espontânea e de grande força de convencimento. Está enraizada em crenças já consolidadas e se utiliza de palavras respeitáveis como natureza, dignidade da vida, ética e valores desejáveis, como o amor, a solidariedade e a responsabilidade..$^{32}$ É o que se considera correto

28 Frankena, William K. Ética. Rio de Janeiro: Zahar, 1969. p. 102-103

29 Maturana, R. Humberto; Varela, G. Francisco. El árbol del conocimiento: las bases biológicas del entendimiento humano. Buenos Aires: Editorial Universitária, s.d., p.164. Veja uma primeira crítica ao fundacionismo de Maturana em Heemann, A. Da natureza à ética: esboço para uma análise das recorrências à natureza. Cadernos de Desenvolvimento e Meio Ambiente da UFPR. Curitiba, n. 3, p.61-68. 1996. A expressão "guilhotina" é explicada em Sánchez Vázquez, Adolfo. Ética. Rio de Janeiro: Civilização Brasileiral, 1983, p. 219, 220. A norma natural não assume automaticamente o caráter axiológico. O deve ser, sob um olhar relativista, será uma condição externa ao plano natural e decorrente da valoração humana.

30 Baseado em Heemann, op. cit, p. 87-88.

31 Como exemplo desse concordismo, citou-se, anteriormente, Teilhard de Chardin.

32 Obstáculos epistemológicos, uma expressão de G. Bachelard. 
e se espera que todos nutram simpatia por eles. Dificilmente alguém não será levado pela força persuasória de tais argumentos. Mas atenção! Trata-se apenas de um apelo psicológico. Eles podem (e devem) receber nossa adesão, mas, sob uma perspectiva relativista, nenhum poderá ser elevado à categoria de fundamento da ética sob o argumento de que se trata de uma derivação da natureza.

Outrossim, o apelo psicológico elevado à categoria de fundamento, por uma questão de coerência, também não poderia dar lugar a legitimações daquilo que se considera deplorável, como, por exemplo, o egoísmo, a exploração, a desigualdade de direitos, etc., que também podem ser ou vir a ser demonstrados como naturais?

Assim, é possível sugerir que aquela certeza ou "conclusão inevitável" 33 alardeada pelo sábio brota, isto sim, de sua filosofia espontânea, ${ }^{34}$ em especial do componente idealista, e não da objetividade e de uma lógica infalível como pretende o seu discurso.

\section{A falácia contranaturalista}

Trata-se de um equívoco, no debate atual, que consiste em condicionar a justificativa dos princípios éticos e a garantia dos direitos de igualdade política e social à verificabilidade dos fatos da natureza. Emerge, principalmente, de algumas réplicas culturalistas às pretensões biologizantes na explicação de comportamentos humanos. Em reação à tendenciosidade, subjacente no discurso reducionista da ciência, seus opositores cometem um tipo de falácia ao concentrarem esforços para desautorizá-lo cientificamente. O debate que deveria correr no plano dos direitos e da ideologia, de um modo geral, é, então, desviado para os fatos da natureza. ${ }^{35}$ Uma confusão entre crítica ideológica e crítica epistemológica?

Desfilam aqui aqueles temas que causam grande celeuma, a exemplo da identidade de gênero, do gene egoísta, da biologia da inteligência, etc. O equívoco, no caso da inteligência, por exemplo, consistiria na idéia de que a igualdade de direitos pressupõe a ausência de diferenças inatas. Em conseqüência, seria necessário demonstrar que não são significativas as diferenças nos dons mentais e físicos das pessoas. Aqui não houve um desvio na discussão? Ela deveria transcorrer no plano dos direitos, mas foi desviada (Verschiebung, segundo Freud) para o plano da verificabilidade funcional, fatual, natural, científica. Para uma posição relativista, não se trata de derivar a decisão axiológica do plano natural, mas apenas de levar em conta esse plano.

Incluindo a posição intuicionista ${ }^{36}$ ao que já foi analisado, podem-se apontar três modalidades de recorrências à natureza em face da ética, conforme segue.

\begin{tabular}{c|c|c}
\hline \multicolumn{3}{c}{$\begin{array}{c}\text { Plano Prescritivo-Ético } \\
\text { (O que deve ser) } \\
\uparrow\end{array}$} \\
\hline $\begin{array}{c}\text { Intuicionismo } \\
\begin{array}{c}\text { A intuição tem } \\
\text { natures na }\end{array}\end{array}$ & $\begin{array}{c}\text { Deriva logicamente } \\
\text { da natureza }\end{array}$ & $\begin{array}{c}\text { A natureza é } \\
\text { uma variável } \\
\text { levada em conta }\end{array}$ \\
\hline \multicolumn{3}{c}{$\begin{array}{c}\uparrow \\
\text { Plano Descritivo-Natural } \\
\text { "O que é)” }\end{array}$} \\
\hline
\end{tabular}

Se os deuses não são medida, se a natureza não o é, resta o homem

Esse enunciado de Schüler $^{37}$ ajuda a compreender o drama da condição humana, em especial nesses tempos pós-modernos. A natureza não contém valores em

33 Expressão utilizada por Aristóteles e, atualmente, por Maturana, entre outros.

34 Em diálogo com Louis Althusser, é apresentada uma análise mais desenvolvida sobre a filosofia espontânea do sábio em Heemann, op. cit., p. 154-157.

35 Baseado na reflexão desse tema em Heemann, op. cit., p. 94, 95, 103, 198, 199, tendo como principais referências Simpsom, George Gaylord. A biologia e o homem. São Paulo: Cultrix, 1974, p. 149 e Fromm, Erich. Sexo e caráter. In: O dogma de Cristo. Rio de Janeiro: Zahar, 1978, p. 87-102.

36 Para o intuicionismo, os princípios éticos são auto-evidentes.

37 De uma reflexão de Schüler sobre os enunciados de Protágoras. Conforme Schüler, Donaldo. O homem que não sabia jogar. Porto Alegre: Movimento, 1998, p. 39, 47. 
si, mas ela produziu NATURALmente um ser que valora. É um produto da história da vida, conjecturam os etólogos. Poderia ter sido moldado de outro jeito, sem as noções de tempo e de espaço, sem as indagações de causa e finalidade. Poderia ser diferente, mas não é! $\mathrm{O}$ homem que aí está exige um significado, diria Heidegger. É a manifestação do imbatível instinto mitopoiético. ${ }^{38}$

Peirce conjectura que seria vantajoso para o animal ocupar-se com visões agradáveis e estimulantes, independentemente de serem verdadeiras ou não. ${ }^{39}$ Assim, um processo que não tem compromisso com a eqüidade poderia ter dado margem a uma falaciosa inclinação ao cérebro que se complexificou e adquiriu a capacidade para imaginar seres ausentes ou inexistentes.

Nessa linha de pensamento, Lacan dizia que o mundo das palavras cria o mundo das coisas. Então, o significado (imagem mental) também pode conferir existências imaginárias, dispensando o referente. Um cérebro que funciona assim não precisará das existências empíricas.

Mas nessa ligação imaginária com o mundo habitará o maior tormento que a humanidade já conheceu: a ansiedade! Há uma ansiedade que decorre de uma invasão recíproca. Seres externos adquirem o poder de invadir a mente que, por sua vez, também invade o mundo com imagens mentais. Para fazer frente a essa alternância esquizofrênica, instala-se no órgão do pensamento a mitopoiese, uma organização ilusória, prática e necessária.

Morin, o interdisciplinar, especula que a consciência da morte estaria na gênese desse ilusório. Ela seria a mais cruel e eficiente estratégia que a vida produziu para o sucesso de seu desígnio maior: a continuidade de si mesma. Quando começava a tornar-se humano, o homem não suportou acreditar na morte. É o que atestam as sepulturas. Enterrava seus mortos com ritos, em uma atmosfera mágica, de recusa à perda sofrida. A morte poderia ser vencida. Um cérebro já desenvolvido permite que no sonho o morto retorne ao convívio dos vivos. Uma proeza que independe do tempo e do espaço. Imagens do passado se tornam presentes e se projetam para o futuro de um modo mágico e sobrenatural. As representações na pintura, no rito e na linguagem ampliam essa capacidade, que também amplia a incerteza, o conflito em face do imaginário e do real. ${ }^{40}$

Nessa viagem sem retorno, o ser valorizante sempre quis decifrar sentidos ocultos em um universo cujo único sentido, quem sabe, é não ter sentido algum. ${ }^{41}$ Depois do desencanto, pelos menos, nenhum sentido predeterminado.

É o abismo aberto entre a natureza e quem dela se distanciou. Uma heróica luta do "senhor de todos os caminhos e sem caminho algum, porquanto todos os caminhos o levam a nada". ${ }^{42}$ Ao desnudar o ilusório, só resta ao homem a reconquista do nada que descobriu. No desamparo da liberdade, solitário e condenado a decidir terá que pensar em um "comportamento ético voltado para o futuro, em uma ética em que a ação não se dirige a um fim já sabido". É a ética em permanente construção.

38 O instinto mitopoiético é uma categoria hipotética (heurística) da etologia. Esse instinto seria o responsável pelas indagações fundamentais do homem e o motivador principal da gênese dos mitos, religiões, ideologias e princípios éticos fundamentais. 39 Peirce, Charles Sanders. Semiótica e filosofia. São Paulo: Cultrix, 1972, p. 74.

40 Baseado em Morin, Edgar. O enigma do homem. São Paulo: Círculo do Livro, 1973, p. $115-118$ e citado por Heemann, op. cit. 41 Do diálogo com a reflexão de Schüler, op. cit. p. 70-71, sobre o poeta Fernando Pessoa.

42 As citações foram retiradas de Schüler, op. cit., e aproximadas de uma reflexão que se encontra em Heemann, op. cit., em especial nas p. 206-214. 


\section{REFERÊNCIAS}

ARISTÓTELES. Ética à Nicômaco. ed. In: Os Pensadores. São Paulo: Abril Cultural, 1973. v. 9.

$$
\text { Metafísica, I, 3, 983a 24-33. }
$$

BARKER, Ernest. Teoria política grega. Platão e seus predecessores. Brasília: Ed. da UNB, 1978.

BERLIN, Isaiah. Vico e Herder. Brasília: Ed. da Universidade de Brasília.

CASINI, Paolo. As filosofias da natureza. Lisboa: Editorial Presença, 1979.

CASTORIADIS, Cornelius. As encruzilhadas do labirinto II: os domínios do homem. Rio de Janeiro: Paz e Terra, 1987.

Castoriadius: a voga humanista oculta ausência de política. Entrevista concedida a Fernando de Barros e Silva. Folha de São Paulo, São Paulo, 07 set. 1991. Letras, p. 6.

FRANKENA, William K. Ética. Rio de Janeiro: Zahar, 1969.

FROMM, Erich. Sexo e caráter. In: O dogma de Cristo. Rio de Janeiro: Zahar, 1978.

GAARDER, Jostein. O mundo de Sofia: romance da história da filosofia. São Paulo: Companhia das Letras, 1995.

GLEISER, Marcelo. A dança do universo: dos mitos da criação ao Big Bang. São Paulo: Companhia das Letras, 1997

HABERMAS, J. Erläuterungen zur Diskursethik. Frankfurt: Suhrkamp, 1991.

HEEMANN, A. Da natureza à ética: esboço para uma análise das recorrências à natureza. Cadernos de Desen- volvimento e Meio Ambiente da UFPR. Curitiba, n. 3, p. 61-68. 1996. 1998. . Natureza e ética. 2. ed. Curitiba: Ed. da UFPR, LENOBLE, Robert. História da idéia de natureza. Rio de Janeiro: Edições 70, 1990.

MORIN, Edgar. O enigma do homem. São Paulo: Círculo do Livro, 1973.

MATURANA, R. Humberto; VARELA, G. Francisco. El árbol del conocimiento: las bases biológicas del entendimiento humano. Buenos Aires: Editorial Universitária, s.d.

MOORE, George Edward. Principia ethica. Cambridge: Cambridge University Press, 1968.

NAHRA, Cinara; WEBER, Ivan Ingo. Através da lógica. Petrópolis: Vozes, 1997.

PEIRCE, Charles Sanders. Semiótica e filosofia. São Paulo: Cultrix, 1972

SIMPSON, George Gaylord. A biologia e o homem. São Paulo: Cultrix, 1974.

SÁNCHEZ VÁZQUEZ, Adolfo. Ética. Rio de Janeiro: Civilização Brasileira, 1983, p. 219, 220.

SCHÜLER, Donaldo. O homem que não sabia jogar. Porto Alegre: Movimento, 1998.

SEVERINO, Antônio Joaquim. Filosofia. São Paulo: Cortez, p. 120,121, 1994.

WHITEHEAD, Alfred North. O conceito de natureza. São Paulo: Martins Fontes, 1993. 